\title{
An Integrated Rock Typing Approach for Unraveling the Reservoir Heterogeneity of Tight Sands in the Whicher Range Field of Perth Basin, Western Australia
}

\author{
Rahim Kadkhodaie Ilkhchi' ${ }^{1}$, Reza Rezaee ${ }^{2}$, Reza Moussavi Harami ${ }^{*}$, Henrik Friis ${ }^{3}$, \\ Ali Kadkhodaie Ilkhchi ${ }^{4}$ \\ ${ }^{1}$ Department of Geology, Ferdowsi University of Mashhad, Mashhad, Iran \\ ${ }^{2}$ Department of Petroleum Engineering, Curtin University, Perth, Australia \\ ${ }^{3}$ Department of Geoscience, Aarhus University, Aarhus, Denmark \\ ${ }^{4}$ Department of Earth Science, Faculty of Natural Science, University of Tabriz, Tabriz, Iran \\ Email: rahimkadkhodaee2005@yahoo.com, r.rezaee@curtin.edu.au, ${ }^{*}$ moussavi@um.ac.ir, \\ henrik.friis@geo.au.dk, kadkhodaie ali@tabrizu.ac.ir
}

Received 24 June 2014; revised 18 July 2014; accepted 14 August 2014

Copyright (C) 2014 by authors and Scientific Research Publishing Inc.

This work is licensed under the Creative Commons Attribution International License (CC BY). http://creativecommons.org/licenses/by/4.0/

(c) (i) Open Access

\section{Abstract}

Tight gas sands in Whicher Range Field of Perth Basin show large heterogeneity in reservoir characteristics and production behavior related to depositional and diagenetic features. Diagenetic events (compaction and cementation) have severely affected the pore system. In order to investigate the petrophysical characteristics, reservoir sandstone facies were correlated with core porosity and permeability and their equivalent well log responses to describe hydraulic flow units and electrofacies, respectively. Thus, very tight, tight, and sub-tight sands were differentiated. To reveal the relationship between pore system properties and depositional and diagenetic characteristics in each sand type, reservoir rock types were extracted. The identified reservoir rock types are in fact a reflection of internal reservoir heterogeneity related to pore system properties. All reservoir rock types are characterized by a compacted fabric and cemented framework. But distribution and dominance of diagenetic products in each of them depend on primary depositional composition and texture. The results show that reservoir rock typing based on three aspects of reservoir sandstones (depositional properties, diagenetic features and petrophysical characteristics) is a suitable technique for depiction of reservoir heterogeneity, recognition of reservoir units and identifying factors controlling reservoir quality of tight sandstones. This methodology can be used for the other tight reservoirs.

\footnotetext{
"Corresponding author.
} 


\section{Keywords}

\section{Tight Sands, Electorofacies, Hydraulic Flow Unit, Rock Type, Reservoir Characteristics}

\section{Introduction}

Tight gas sands, as a type of unconventional reservoirs, have been studied and recognized in several countries such as United States of America, Canada, Australia and China. The importance of these reservoirs has been increasingly recognized in recent years because these reservoirs, in spite of their low porosity and especially low permeability, have large reserves of hydrocarbon that is obtainable if they are characterized exactly and extracted by new techniques. Generally, tight gas sand is defined as a low permeability reservoir that need specific treatments such as advanced drilling technology, correct way of completion and stimulation jobs for having a commercial gas production [1].

There are many studies on tight gas focusing on different aspects of these reservoirs both geologically and petrophysically. Stroker et al. [2] studied diagenesis of tight gas sand reservoir of Upper Cretaceous Mesaverde Group in the Picean Basin of Colorado, and they concluded porosity to be a complicated function of compaction, cementation and dissolution. Prodanovic et al. [3] in their study of diagenetic alteration by numerical simulation in tight gas sandstones showed that cementation has the main effect on gas trapping in these reservoirs. Rezaee et al. [1] estimated permeability of the tight gas sands in Western Australia from mercury injection capillary pressure and nuclear magnetic resonance data. They showed that pore throat radius at $10 \%$ mercury saturation $\left(\mathrm{r}_{10}\right)$ yields the best correlation with permeability. Bahrami et al. [4] studied hydraulically fractured tight sand gas reservoirs of the Perth Basin in Western Australia and introduced the importance of formation damage by water blocking. Ziarani and Aguilera [5] estimated pore-throat radius and tortuosity from formation resistivity data for tight-gas sandstone reservoirs. In recent years, there are also many studies on tight gas reservoirs in China that have considered different aspects of their reservoir characterization (e.g. [6]-[10]).

Reservoir sands of the Whicher Range gas field in the Perth Basin of Western Australia are mainly considered as tight gas sands due to their low porosity and low permeability. Production from these sands is not stable and cost-effective. On the other hand, uses of certain techniques such as hydraulic fracturing to stimulate the reservoir and improve the production, have not been successful until now. It is, therefore, the target of this study to characterize these sands related to their internal heterogeneity and to determine main factors controlling reservoir behavior related to pore system properties. In this respect, we have applied reservoir rock typing based on the integration of the depositional properties and diagenetic features associated with petrophysical characteristics as a comprehensive method to characterize reservoir sandstones. The results show the effect of both depositional and diagenetic properties on pore system of tight sands in the Whicher Range gas field.

\section{Geological Setting}

Perth Basin is an N-S trending, long and narrow and asymmetrical rift basin (Figure 1(a)) located in the southwest of Western Australia [11]. The eastern boundary is the Darling Fault, and the basin extends offshore to the continental-oceanic boundary. The basin contains up to $12 \mathrm{~km}$ of Ordovician and mid-Carboniferous to Cretaceous, primarily non-marine to shallow-marine strata, below extensive thin, mostly non-marine, Cenozoic cover [12]. Perth Basin hosts some tight sand reservoirs situated in both southern and northern sectors. The Whicher Range field, the target of this study, with gas trapped in deep burial $(\sim 4 \mathrm{~km})$ tight sands is one of the most important fields of the basin. The field is located in a large anticline structure in the Bunbury Trough, and five wells have been drilled in this structure so far. The sandstones of Willespie Formation of Late Permian age (Figure 1(b)) constitute the main reservoir rock of the field [13].

\section{Data and Methodology}

In order to characterize tight sands of Whicher Range field, we used well log and core data from four drilled wells in the field. Facies and diagenetic features were recognized and interpreted based on core, cutting and microscopic (polarizing, SEM) studies. In order to study and classify reservoir sandstones in relation to their reservoir 


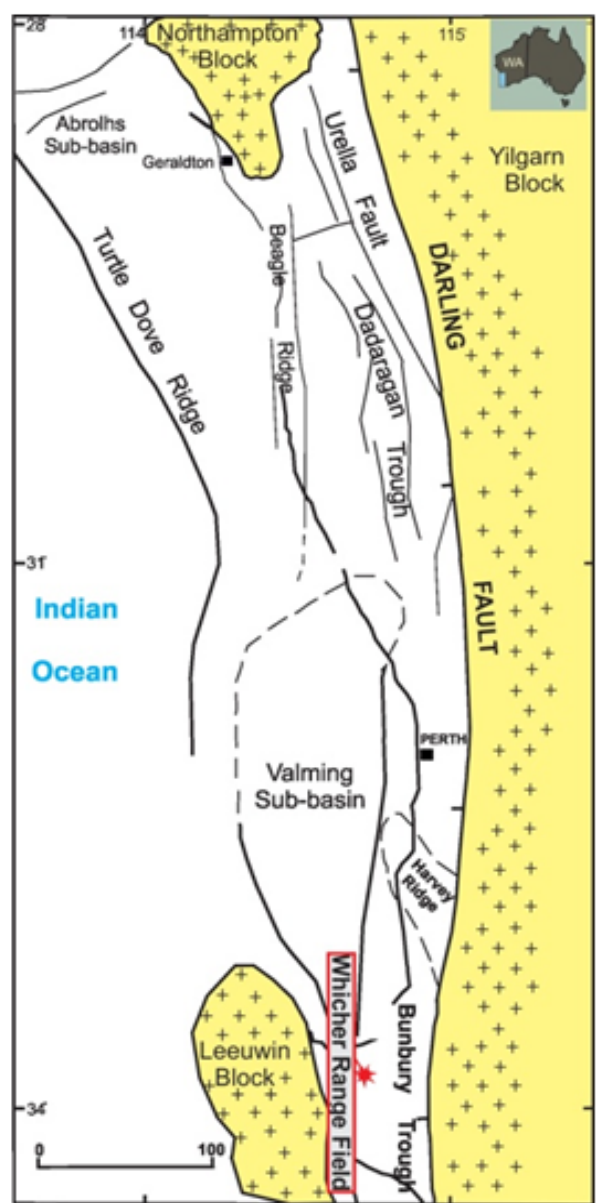

(a)

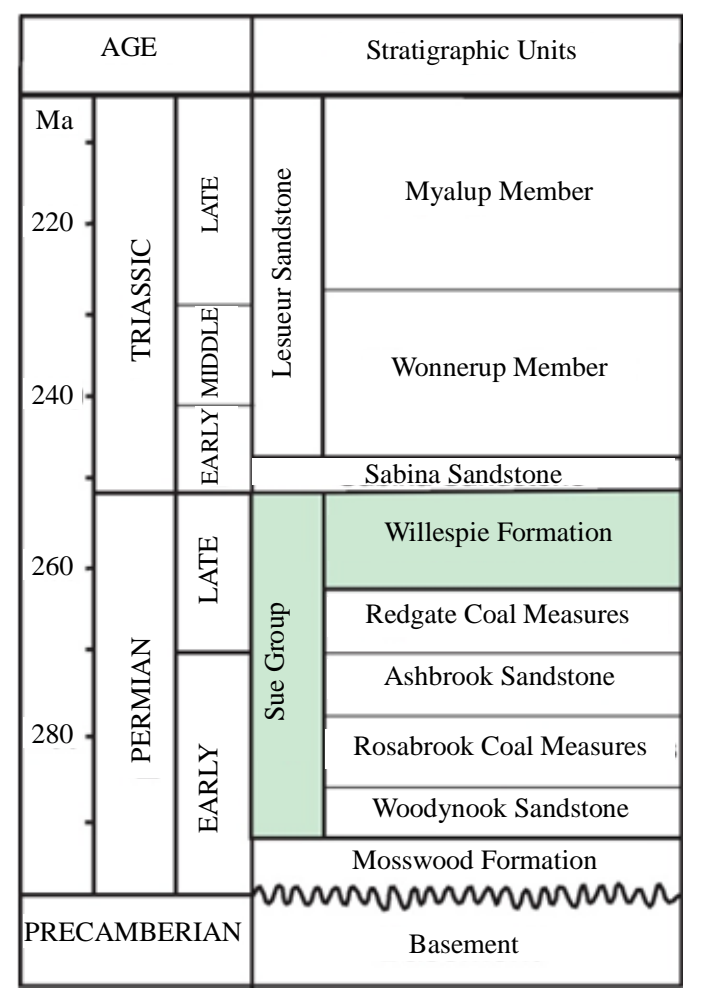

(b)

Figure 1. (a) Location map of Perth Basin in the southwest of Western Australia. The location of Whicher Range field in Bunbury Trough has been shown in the southern Perth Basin [15]. (b) Permian to Triassic Lithostratigraphy column of the southern Perth Basin [13]. In this column, Late Permian Willespie Formation from Sue Group, as the main reservoir rock of the Whicher Range field, has been highlighted.

characteristics, pterophysical rock typing was used in terms of hydraulic flow units (HFU) and electrofacies concepts. Core porosity and permeability data were used for recognition and differentiation of HFUs. Reservoir electrofacies were determined based on well log data clustering using the cluster tree method by using Matlab software. In an effort to find a reasonable and clear relationship between recognized petrophysical rock types with their depositional and diagenetic characteristics, we described reservoir rock types. Each rock type is characterized by three main parameters including depositional facies (texture and composition), diagenetic facies (diagenetic features), and petrophysical characteristics (pore system properties).

\section{Detrital Composition}

Willespie Formation is mainly composed of poorly sorted feldspathic sandstones (feldspathic arenite to subfeldspathic arenite according to Folk et al. [14], Figure 2), with subordinate conglomerate, siltstone, shale and sporadic lenticular coal seams [13]. Sandstones are generally texturally and compositionally immature to submature. Texturally, sandstones show a wide range in size from very fine to very coarse and granular. Framework grains are mostly sub-angular to sub-rounded. Sorting is generally poor, but is better in fine grained facies. Monocrystalline quartz is the dominant grain type. Feldspar (potassium feldspar and plagioclase) is usually the second most abundant framework grain. Less abundant framework grains are rock fragments (metamorphic, igneous and sedimentary lithics), micas (biotite and muscovite), and heavy minerals (garnet, zircon, tourmaline, 

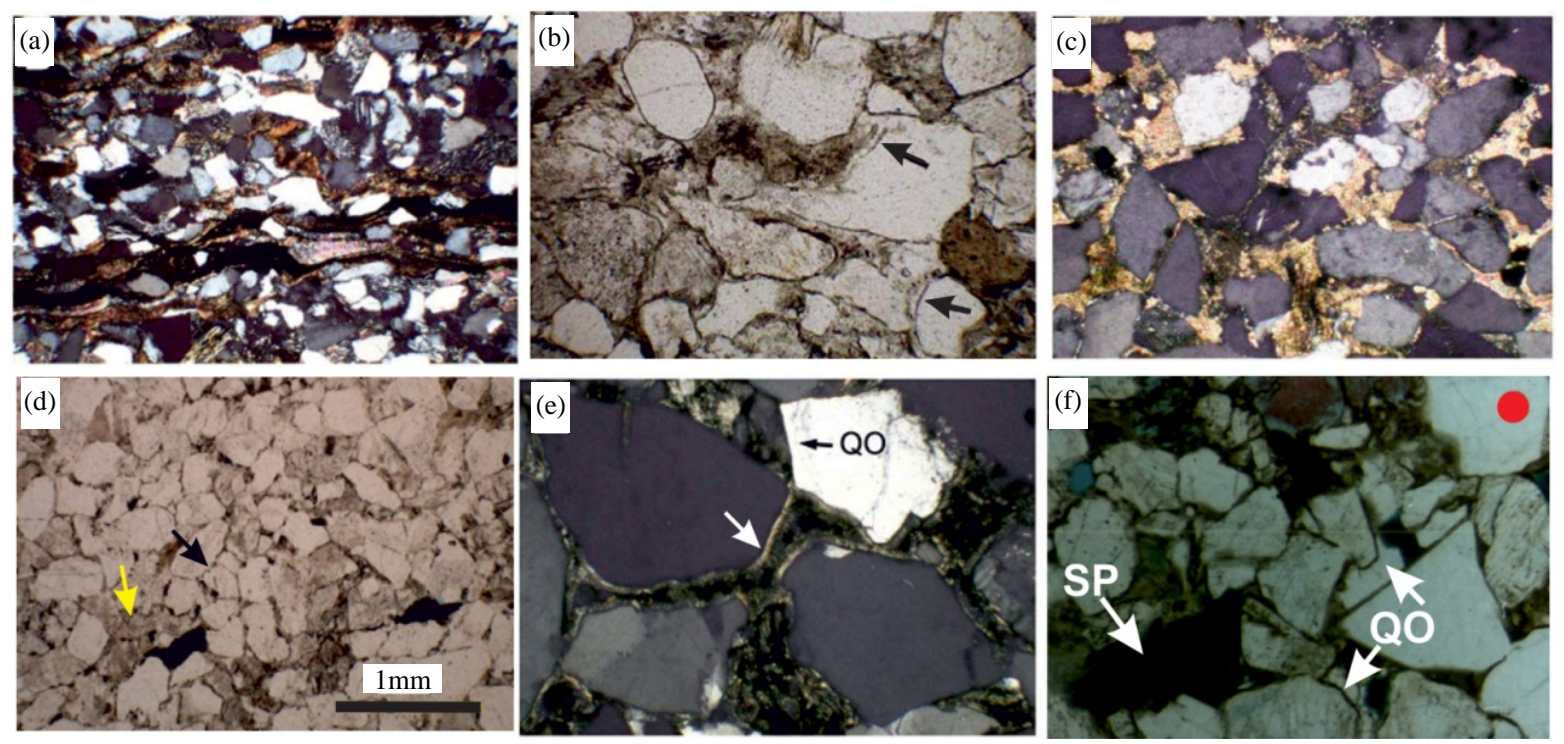

Figure 2. Photomicrograph showing common diagenetic features in Whicher Range sandstones. (a) Fine sandstone with common quartz, feldspar and laminae defined by biotite (brown flakes), carbonaceous stringers (black) and minor muscovite (bright birefringence). (WR4-3946.25 m, Field of view is $2.3 \mathrm{~mm}$ ). (b) Photomicrograph of quartz overgrowths post-dating early chlorite coating (black arrows) (WR4-3935.85 m, PPL, field of view $=1.15 \mathrm{~mm}$ ). (c) Calcite cement as pore-filling cement in a medium grained sandstone (WR4-3915.70 m, field of view $=3 \mathrm{~mm}$ ). (d) Compacted fabric with long and some suture grain contacts (black arrow) in a moderately well sorted, sub-angular to sub-rounded, medium grained sandstone. Yellow arrow indicates ductile deformation of a framework grain. (e) Well developed pore-lining and pore-filling clay cements (white arrow) (WR4-3927.45 m, field of view = $1.75 \mathrm{~mm}$ ). (f) Photomicrograph showing several large, secondary pores as well as numerous partially cemented primary pores $(\mathrm{WR} 2-4169.2 \mathrm{~m}$, red dot $=0.03 \mathrm{~mm})$. QO = quartz overgrowths, $\mathrm{SP}=$ secondary pores.

and epidot). In some facies, the abundance of micas and garnet significantly increases. Based on the regional geology, the existing core interpretation and vertical facies variations, a fluvial-paludal system is considered for the Willespie Formation.

\section{Diagenetic Overprints}

Diagenetic events including compaction, cementation and dissolution during early to burial stages of diagenesis have severely affected the reservoir sandstones of the Whicher Range field. The effects of these processes are clearly seen in modification of the primary pore system properties which, in turn, control the reservoir quality and production behavior of the field. Photomicrographs of common diagenetic features within the reservoir sandstones have been shown in Figure 2.

\section{Pore System in Whicher Range Sandstones}

The pore system in Whicher Range sandstones contains both primary and secondary pores. Both pore types have been cemented by clays, quartz and carbonates. The secondary pores are connected through the residue of the strongly cemented primary pore network, and its permeability will fundamentally determine the reservoir quality of the sandstones. In addition, micro-porosity related to authigenic clays such as kaolinite and illite/smectite with large surface area supports high irreducible water saturation. All of these features define the reservoir sandstones as a type of unconventional reservoirs named as tight sand or tight gas sands. In Figure 3, some SEM photographs of pores system of the reservoir sandstones affected by authigenic clay minerals have been demonstrated.

\section{Relationship between Diagenetic Products and Tightness in Reservoir Sanstones}

In tight gas sandstones of Whicher Range, as already discussed, diagenetic processes have severely modified 

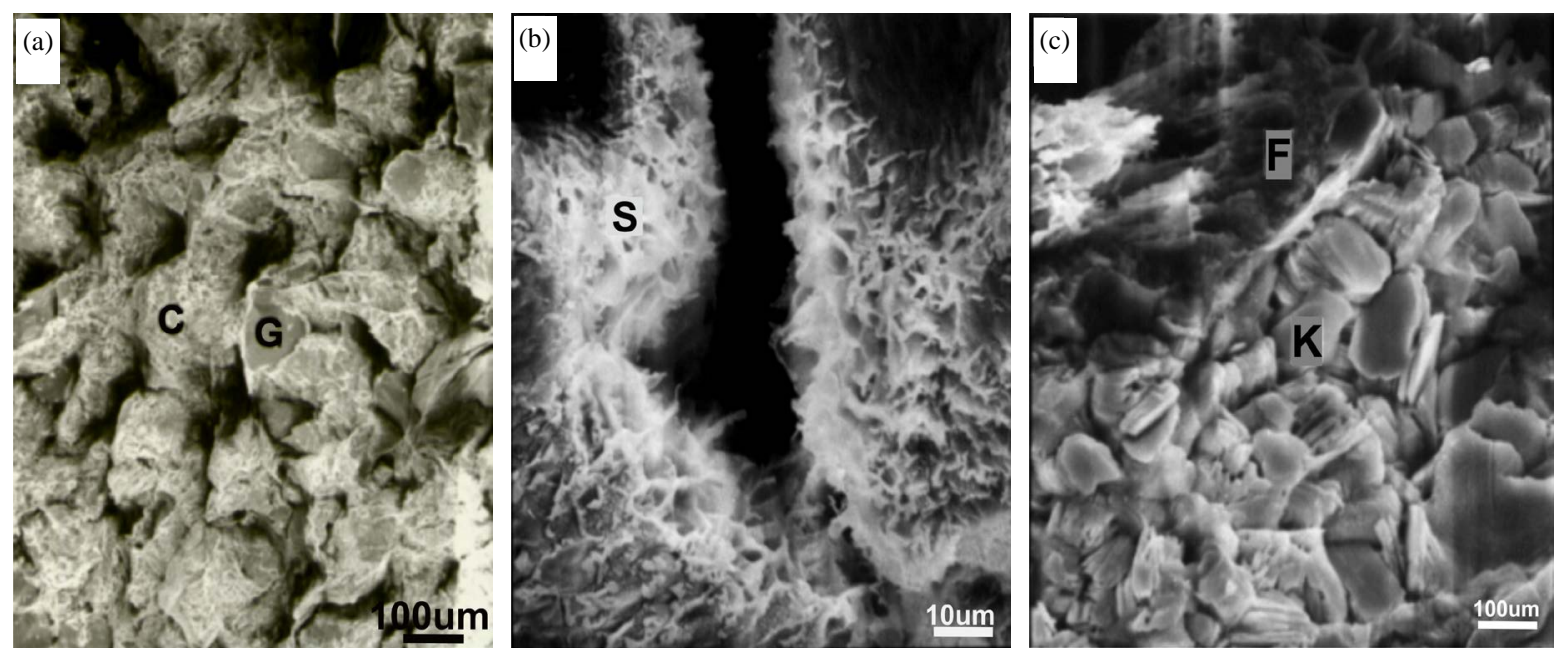

Figure 3. SEM photographs of clay minerals in the Whicher Range sandstones. (a) General view of sample showing detrital grains (G) surrounded by clay (C) (WR2-3942.5 m). (b) The pore system is coated with a well-developed film of smectite (S). Note the cellular morphology which gives the coat a large surface area (WR2-4171.1 m). (c) The primary pores are often filled with kaolinite booklets (K) and are coated with a film of iron oxide (F) (WR2-3945.51 m).

pore system quantitatively and qualitatively and finally resulted in sandstones with compacted fabric and low porosity and low interconnected pore spaces. The results from core studies, petrography interpretation and SEM photographs show that diagenesis has close relationship with primary depositional characteristics, both texture and composition, of Whicher Range sands. In such deep sandstones, compaction has a significant effect on pore systems in the first stages of diagenesis, especially in fine grained facies and in sandstones with a large proportion of ductile framework grains. This can be evidenced by physical deformation and bending of soft grains such as micas (Figure 2(a)) and some rock fragments (Figure 2(d)) around harder framework grains. Precipitation of quartz overgrowths, carbonate cements and authigenic clay minerals mostly occurred after significant physical compaction of the reservoir sandstones.

Quartz overgrowths generally have sparse and limited distribution in the reservoir although they are abundant in some quartz rich facies. These cements apparently have more important effect on porosity than permeability. Authigenic clay minerals have extensive distribution and as they are occluding the pore spaces and pore throats they are the main diagenetic cements in relation to reducing the permeability within the reservoir sandstones. Based on microscopic evidence, authigenic clays mostly derived from the breakdown of feldspar and detrital mica, and they infill the interstices between the framework grains. So, distribution of authigenic clay minerals as grain coating and pore lining (i.e. chlorite, mixed layer illite-smectite) as well as pore filling (mainly kaolinite) has intimate relationship with primary mineralogical composition of the sandstones. Calcite cementation has had an important role on porosity and permeability reduction, but it has a local distribution in the reservoir. Dissolution of unstable grains such as plagioclases is considered as a positive process on reservoir properties and to some extent compensates the effect of compaction and cementation, but the resultant secondary pores are isolated and are often partly to completely filled with authigenic cements, especially clay minerals. So, it can be concluded that tightness in Whicher Range sandstones is a complex function of interaction between primary depositional properties and post-depositional diagenetic processes. In this respect, compaction and cementation are two main factors controlling pore system characteristics of the Whicher Range sandstones. As a result, tight reservoir sandstones with compacted fabric, highly cemented and low interconnected pore systems have been produced.

\section{Petrophysical Characteristics of Reservoir Sandstones}

The results from core studies and microscopic analysis of Willespie Formation sandstones show an internal heterogeneity related to depositional properties and diagenetic features within the reservoir. This, in turn, is reflected in petrophysical characteristics of the sandstones. In this regard, reservoir behavior can be interpreted based on pore system properties controlled by depositional and post-depositional characteristics of the reservoir 
sandstones. Based on sedimentary rock typing, reservoir units (sand and silt) of Whicher Range sandstones were distinguished from non reservoir units (shale) using clustering of well log data and verification of results with petrographic data [16]. In this study, in order to characterize the reservoir sandstones and to recognize the main factors controlling reservoir quality, reservoir units (sandy and silty intervals) first studied petrophysically in terms of hydraulic flow unit and electrofacies concepts resulted in separation of petrophysical rock types. Then, these rock types based on pore system properties associated with depositional and diagenetic attributes were interpreted, resulted in differentiation of reservoir rock types.

\subsection{Petrophysical Rock Typing Based on Hydraulic Flow Units}

Rock typing based on the hydraulic flow unit (HFU) concept is a technique by which the reservoir rocks are petrophysically classified into certain reservoir units related to pore properties within each unit. In the literature, a hydraulic flow unit is considered as a part of reservoir rock within which geological and petrophysical properties, controlling the fluid flow, are consistent and predictably different from properties of other parts of reservoir rocks ([17] [18]). Amaefule et al. [19] defined Hydraulic Flow Unit as the elements of the reservoir rock which have similar averages of petrophysical rock properties that affect fluid flow. In this study, we use the method of Amaefule et al. [19] for differentiation of hydraulic flow units in the reservoir that has been recognized and used as a practical and common method by many researchers (e.g., [20]-[23]). The stages are summarized as follows:

1) Calculation of reservoir quality index based on porosity and permeability data and according to Amaefule et al. [19] method:

$$
\mathrm{RQI}=0.0314 \sqrt{k / \varphi}
$$

where RQI is reservoir quality index, $\mu \mathrm{m}$; $k$ is permeability, $\mathrm{mD}$; and $\varphi$ is porosity in fraction.

2) Calculation of pore to matrix ratio (PMR) using the following equation:

$$
\operatorname{PMR}=\varphi /(1-\varphi)
$$

3) Extraction of flow zone indicator (FZI) by the following correlation:

$$
\mathrm{FZI}=\mathrm{RQI} / \mathrm{PMR}
$$

Some properties of different HFUs associated with cut off values for their differentiation are given in Table 1. Study of identified hydraulic flow units on porosity and permeability plot (Figure 4) shows that each HFU is characterized by a certain district on the plot. This property in fact is related to pore system properties controlling fluid flow in the reservoir. Thus, each hydraulic flow unit can be indicator of a specific reservoir unit with unique pore system properties. Generally, hydraulic flow units in relation to their petrophysical characteristics (Table 1) can be classified into three main groups as follows:

HFU A\&B: low permeable hydraulic flow units A and B are related to very fine grained sands and silts. In these facies, although porosity may be relatively high but their permeability is very low $(<0.1 \mathrm{mD})$. So, they cannot have important role on production behavior in the reservoir. In this respect they are similar to shaly intervals, and we discarded them for more investigation.

\begin{tabular}{|c|c|c|c|c|}
\hline HFU & $\Phi(\mathrm{Fr})$ & Perm (mD) & RQI & $\log$ FZI (cut off) \\
\hline A & 0.16 & 0.02 & 0.01 & $<-1.2$ \\
\hline $\mathrm{B}$ & 0.14 & 0.08 & 0.02 & $-1.2<\log \mathrm{FZI}<-0.8$ \\
\hline $\mathrm{C}$ & 0.11 & 0.22 & 0.04 & $-0.8<\log \mathrm{FZI}<-0.4$ \\
\hline $\mathrm{D}$ & 0.10 & 0.74 & 0.07 & $-0.4<\log \mathrm{FZI}<0.0$ \\
\hline $\mathrm{E}$ & 0.07 & 1.21 & 0.11 & $0.0<\log \mathrm{FZI}<0.4$ \\
\hline $\mathrm{F}$ & 0.05 & 2.14 & 0.20 & $>0.4$ \\
\hline
\end{tabular}

Table 1. Cut off values based on FZI for differentiation of HFUs in the reservoir sandstones, associated with reservoir quality index and average porosity and permeability data. 


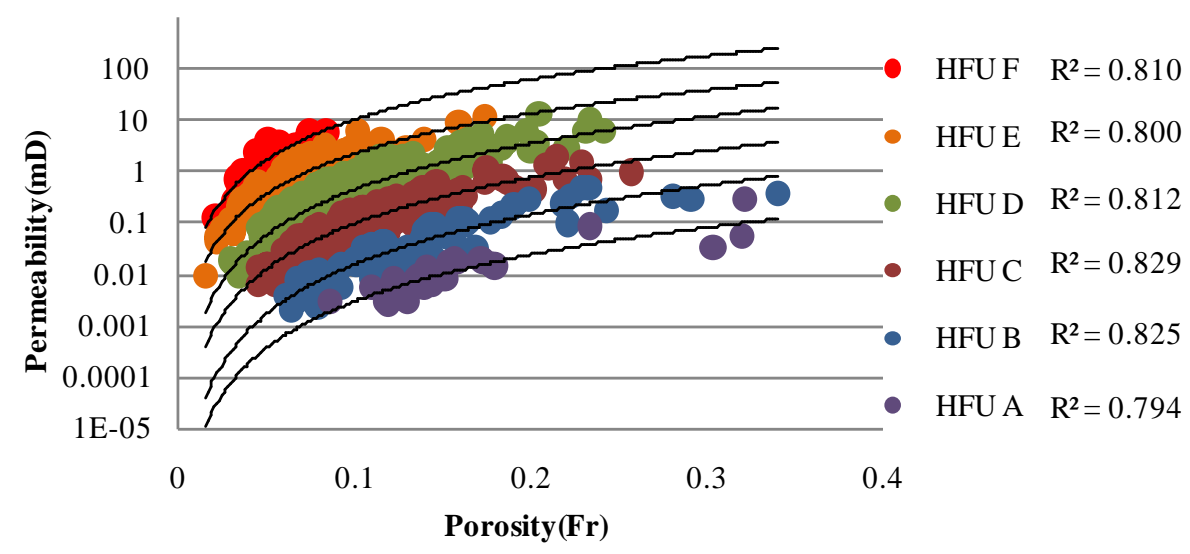

Figure 4. Distribution of different hydraulic flow units on the porosity and permeability plot for the reservoir sandstones.

Two other groups, mainly separated based on porosity value, are HFU C\&D and HFU E\&F with average porosity of $10 \%$ and $6 \%$, respectively (Table 1 ). Based on core and petrographic evidences, sandstone facies in these two groups are very heterogeneous, and change from fine to coarse and very coarse. So, we used data clustering technique based on prtrophysical log responses (DT, NPHI, and RHOB) and pore size to extract petrophysical rock types, and unravel reservoir characteristics in each group individually. Pore size was determined by Equation (4) which was developed by Rezaee et al. [1] for tight gas sands.

$$
\log k=-1.92+949 \log \mathrm{Phi}+2.18 \log _{10}
$$

where $k$ is the dry gas permeability $(\mathrm{mD})$, Phi is porosity (\%) and $\mathrm{r}_{10}$ is the pore throat size (micron) corresponding to the 10th percentile of mercury saturation on a cumulative mercury injection plot.

\subsection{Petrophysical Rock Typing Based on Electrofacies}

In this stage, we use well log data responses based on electrofacies concept to investigate and classify different petrophysical rock types within the reservoir sandstones. Electrofacies approaches are often used to determine rock types from logs. In this regard, electrofacies is applied for a set of log responses which characterizes bed/strata and allows it to be distinguished from others [24]. This response against reservoir rocks is in fact a reflection of variability related to geological and petrophysical properties of the reservoir recorded continuously along the well. Thus, separation of reservoir facies based on available logs known as log facies or electrofacies, can be used as a useful, practical and economical procedure in this regard.

Electrofacies in each group of defined hydraulic flow units (HFU C\&D and HFU E\&F), were determined individually, by hierarchical cluster analysis of well log data. The processed log data (i.e., GR, DT, RHOB, and $\mathrm{NPHI})$ were loaded as an input matrix $(x)$ in MATLAB software workspace, and we pursue the methodology according to the following stages.

Step 1: Compute the distance between data objects. We compute the Euclidean distance (Equation (5)) between pairs of objects as a common method.

$$
d_{r s}^{2}=\left(x_{r}-x_{s}\right)\left(x_{r}-x_{s}\right)^{\prime}
$$

where $d$ for two clusters $r$ and $s$ is the various distances between the vectors $x_{r}$ and $x_{s}$ for an $m$ by $n$ data matrix $x$, which is treated as $m$ (1-by- $n$ ) row vectors $x_{1}, x_{2}, \cdots, x_{m}$.

Step 2: Linking between distance data. In this step, an appropriate linkage function create hierarchical cluster tree from the distance information generated in the first step. We use complete linkage function (Equation (6)) that uses the largest distance between objects in the two clusters, and is more compatible method with the reservoir sandstones:

$$
d(r, s)=\max \left(\operatorname{dist}\left(\operatorname{dist}\left(x_{r i}, x_{s j}\right)\right), i \varepsilon\left(i, \cdots, n_{r}\right), j \varepsilon\left(1, \cdots, n_{s}\right)\right)
$$


Step 3: Dendrogram or cluster tree generation. Hierarchical clustering groups data over a variety of scales by creating a cluster tree or dendrogram. The extracted dendrogram diagrams for the reservoir sandstones in each group of HFUs (HFU C\&D and HFU E\&F) are shown in Figure 5.

Step 4: Extracting of clusters from dendrogram based on cutoff value. An examination, based on trial and error revealed separation of three clusters (EF1, EF2, EF3 for HFU C\&D and EF4, EF5, EF6 for HFU E\&F) on each diagram based on cutoff measure well matched with the reservoir sandstones properties. Each of these
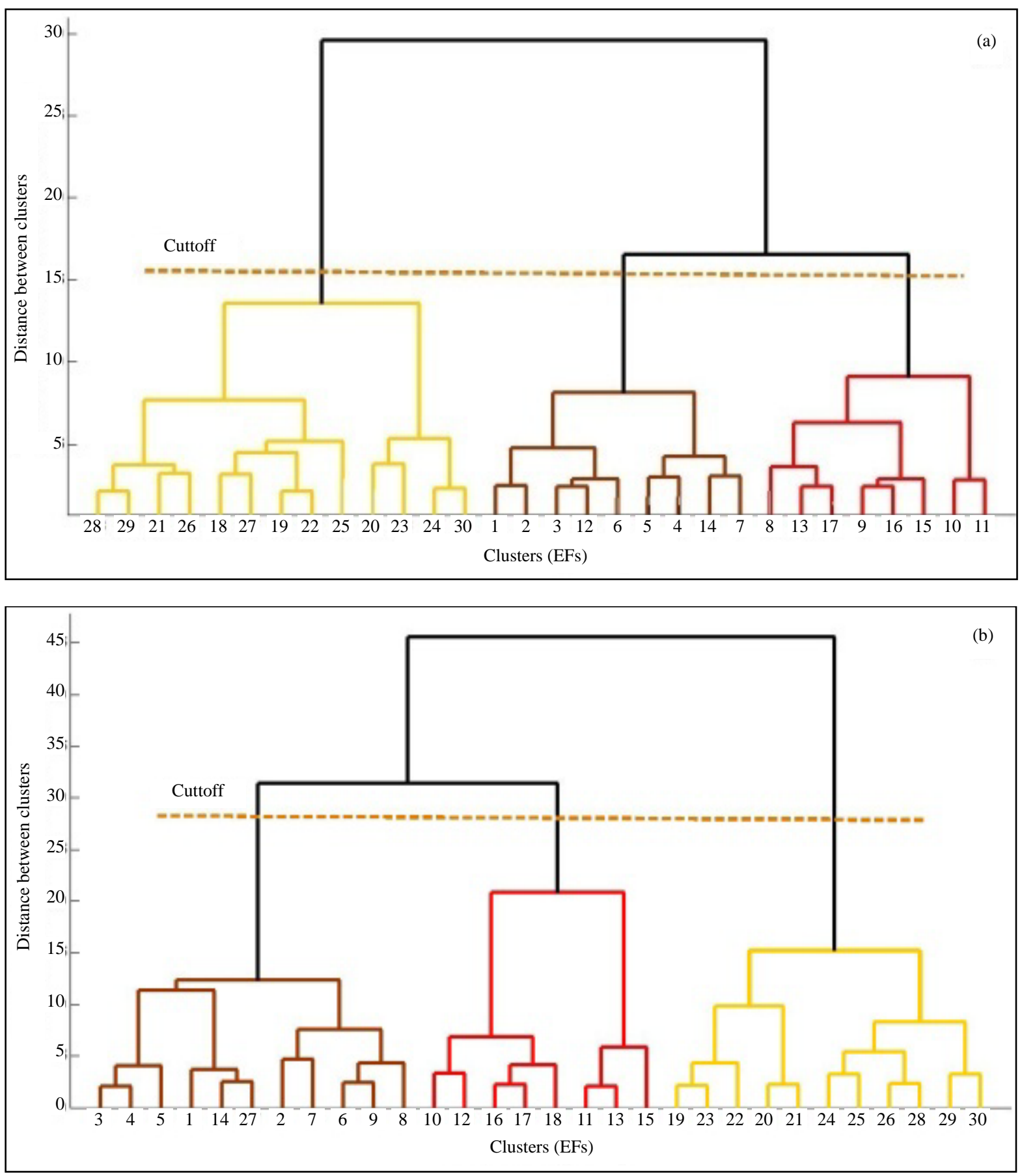

Figure 5. Generated dendrogram diagrams for cluster analysis of reservoir sandstones in each group of hydraulic flow units: (a) (HFU C\&D) and (b) (HFU E\&F). The horizontal dashed line on each diagram shows the cutoff value which based on different clusters is differentiated. 
clusters or electrofacies has certain values of readings or responses of any used well logs that in fact reflects geological (textural and diagenetic) and petrophysical (porosity and permeability) characteristics of the reservoir rocks.

Study of extracted electrofacies related to petrophyical characteristics shows that each electrofacies has specific districts on porosity and permeability plot (Figure 6). This is mostly related to pore system properties. Thus, they can be classified into three main petrophysical groups or sand types including sub-tight $(\mathrm{K}=1-10$ $\mathrm{mD}$; EF3, EF5, and a part of EF4), tight (K = $0.1-1 \mathrm{mD}$; EF1, EF6), very tight $(\mathrm{K}<0.1 \mathrm{mD}$; a part of EF2) sandstones. Facies and petrophysical characteristics of each sand type are as follows.

Very tight to tight sandstones: these sandstones that are mostly related to EF2, consist of fine to medium grained sandstones, in most cases they are micaceous with numerous shale partings. The average porosity and permeability in these sandstones are $7 \%$ and $0.19 \mathrm{mD}$, respectively.

Tight sandstones: these sandstones are related to EF1 and EF6. They consists of medium to coarse and to some extent fine grained sandstones. In some facies mica is dominant with numerous shale partings. Average porosity and permeability for EF1 tight sandstones are $11 \%$ and $0.46 \mathrm{mD}$ respectively and for EF6 tight sandstones they are $4 \%$ and $0.65 \mathrm{mD}$.

Sub-tight sandstones: sandstone facies in this sand type are compatible with EF3 and EF5 and a part of EF4, and consist of medium to coarse and in some case very coarse and granular sands. A minor part of porosity in these sands has remained as intergranular. Facies in EF4, petrophysically change between sub-tight and tight sandstones. Average porosity and permeability for these sand types are respectively: $19 \%$ and $2.83 \mathrm{mD}$ in EF3, $10 \%$ and $2.83 \mathrm{mD}$ in EF5, and 6\% and $1.36 \mathrm{mD}$ in EF4.

\section{Reservoir Rock Typing of the Willespie Formation Sandstones}

Study of tight sands in the Whicher Range field based on hydraulic flow units and reservoir electrofacies, as a type of rock typing, shows some aspects of internal resevoir heterogenity. But other aspects of reservoir characteristics with respect to pore system properties responsible for reservoir bahavior remains unknown. So, in an effort to recognize factors affecting pore systems and resulting reservoir properties, we consider the role of depositional and diagenetic processes on pore systems of sand types in the reservoir. In this respect, in the framwork of what we name reservoir rock typing, we study and analyse three main aspects of reservoir sandstones including depositional properties (texture and composition), diagenetic features (diagenetic facies) and petrophysical characteristics (pore system properties) with each other to show a real picture of reservoir units. Depositional properties that are related to texture and composition of reservoir sandstones, as already discussed, have some control on the pore system and also the distribution of diagenetic products. The appearence of the sandstone

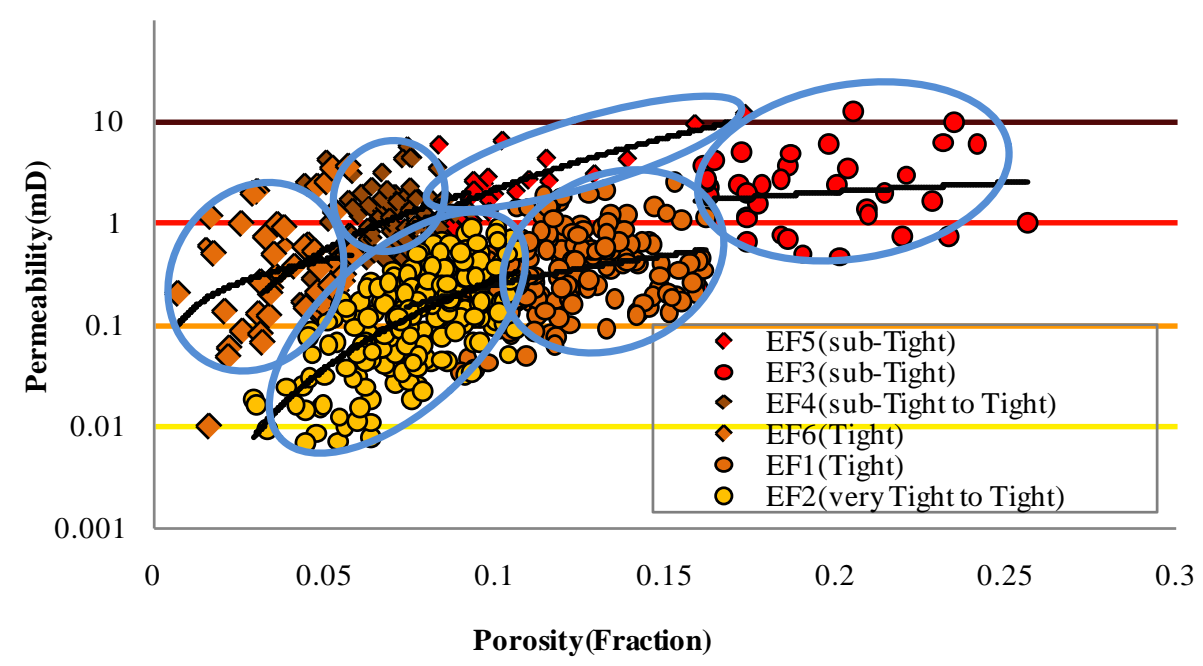

Figure 6. Distribution of different electrofacies related to HFU groups (HFU C\&D and HFU $\mathrm{E} \& \mathrm{~F})$ on porosity and permeability plot. Electrofacies in relation to various sand types have been shown with different colors: very tight to tight $(\mathrm{K}=0.19 \mathrm{mD}$ in average) in yellow, tight $(\mathrm{K}=0.1-1 \mathrm{mD})$ in brown and sub-tight $(\mathrm{K}=1-10 \mathrm{mD})$ in red color. 
facies has been changed as a result of diagenetic activities within the reservoir. This can be observed in compacted fabric and cemented framework of all sand types, and resulted in quantitative and qualitative modification of pore system in these sandstone, as they are considered as tight gas sandstones. Pore system properties of tight sandstones in the Whicher Range field is responsible for production behavior of the reservoir. Thus, knowledge of pore space properties (type, size, volume and pore connection) of the reservoir sandstones, can help in recognition of production zones and interpretation of reservoir behavior in the field. Table 2 summarizes pore system properties and descriptions in relation to different sand types and electrofacies in the reservoir.

\section{Reservoir Rock Types}

Based on the results from the integration of three aspects of the reservoir sandstones (depositional properties, diagenetic features and petrophysical characteristics) reservoir rock types are described. Investigation of different sand types in terms of depositional, diagenetic and petrophysical characteristics resulted in discrimination of eigh reservoir rock types (RRTs). Quantitative and dominant qualitative features of these RRTs are shown in Table 3 and Table 4, respectively.

\section{Interpretation of Reservoir Rock Types in Each Sand Type}

The main findings of reservoir rock typing of tights sandstones are summarized as follows.

- Compaction is a common diagenetic feature in all reservoir rock types. But the effect of these events is more striking in fine grained and mica rich sandstones and also in facies with significant amount of ductile grains and shale partings, especially in very tight to tight sandstones (RRT7).

- Cementation by authigenic clays, Q-overgrowths and calcite has an important role on porosity reduction and limitation of pore connections. In this respect, pore-filling and pore-lining clay cements, mostly derived from alteration of feldspars and micas, have widely been distributed in both primary and secondary pores.

- Quartz overgrowths with sparse distribution within the reservoir sandstones, have mostly affected the pore system through reduction in pore volume. But, the effect of this cement on permeability is not significant.

Table 2. Pore system properties in relation to identified sand types and electrofacies in the reservoir.

\begin{tabular}{|c|c|c|c|c|c|}
\hline \multirow{2}{*}{ Sand type } & \multirow{2}{*}{ Permeability class } & \multirow{2}{*}{ Permeability description } & \multicolumn{3}{|c|}{ Porosity class } \\
\hline & & & Low $(<7 \%)$ & Medium (7\% - 15\%) & High (15\% - 25\%) \\
\hline Very tight & Very low $(<0.1 \mathrm{mD})$ & Non-effective & & & \\
\hline Very tight to tight & Very low-low & Non-effective & EF2 & & \\
\hline Tight & Low $(0.1-1 \mathrm{mD})$ & Poorly connected & EF6 & EF1 & \\
\hline Tight to sub-tight & Low-moderately low & Poorly to moderately connected & EF4 & & \\
\hline Sub-tight & Moderately low (1 - 10 mD) & Poorly to moderately connected & & EF5 & EF3 \\
\hline
\end{tabular}

Table 3. Quantitative parameters for each reservoir rock type of Whicher Range sandstones.

\begin{tabular}{|c|c|c|c|c|c|c|c|c|}
\hline ST & RRT & GR & Vsh & DT & RHOB & $\Phi(\mathrm{Fr})$ & Perm (mD) & $\mathrm{r}_{10}$ (micron) \\
\hline \multirow{2}{*}{ Sub-T } & 1 & 66.57 & 0.25 & 82.92 & 2.23 & 0.19 & 2.84 & 3.10 \\
\hline & 2 & 66.98 & 0.25 & 71.34 & 2.14 & 0.11 & 2.56 & 3.87 \\
\hline \multirow[t]{2}{*}{ Sub-T to $\mathrm{T}$} & 3 & 84.00 & 0.34 & 65.87 & 2.35 & 0.07 & 1.45 & 3.74 \\
\hline & 4 & 66.97 & 0.25 & 73.38 & 2.14 & 0.12 & 0.39 & 1.57 \\
\hline \multirow{2}{*}{$\mathrm{T}$} & 5 & 75.50 & 0.29 & 61.82 & 2.31 & 0.04 & 0.38 & 2.63 \\
\hline & 6 & 69.17 & 0.26 & 69.01 & 2.19 & 0.09 & 0.63 & 2.34 \\
\hline \multirow[t]{2}{*}{$\mathrm{T}-\mathrm{VT}$} & 7 & 80.56 & 0.32 & 67.36 & 2.25 & 0.08 & 0.15 & 1.19 \\
\hline & 8 & 75.64 & 0.29 & 64.43 & 2.57 & 0.05 & 0.13 & 1.20 \\
\hline
\end{tabular}


Table 4. Descriptive characteristics of reservoir rock types defined based on three aspects of reservoir sandstones.

\begin{tabular}{|c|c|c|c|c|c|}
\hline Sand type & $\mathbf{E F}$ & RRT & Depositional facies & Diagenetic facies & Petrophysical characteristics \\
\hline \multirow{2}{*}{$\begin{array}{l}\text { Sub-tight } \\
\text { sand }\end{array}$} & EF3 & 1 & $\begin{array}{l}\text { Medium to coarse trace } \\
\text { very coarse and granular } \\
\text { quartzose channel sand }\end{array}$ & $\begin{array}{l}\text { Compacted fabric, Quartz } \\
\text { overgrowth and clay } \\
\text { cemented framework }\end{array}$ & $\begin{array}{l}\text { Highly porous, moderately low permeable, } \\
\text { poor to fair intergranular porosity, poorly } \\
\text { to moderately connected micro to dissolution } \\
\text { meso pores }\end{array}$ \\
\hline & EF5 & 2 & $\begin{array}{l}\text { Medium to trace coarse and } \\
\text { granular quartzose sand }\end{array}$ & $\begin{array}{l}\text { Compacted fabric, clay } \\
\text { and Q-overgrowth } \\
\text { cemented framework }\end{array}$ & $\begin{array}{l}\text { Moderately porous and moderately low } \\
\text { permeable, poor to fair intergranular } \\
\text { porosity, poorly to moderately connected } \\
\text { micro to dissolution meso pores }\end{array}$ \\
\hline $\begin{array}{l}\text { SUB-tight to } \\
\text { tight sand }\end{array}$ & EF4 & 3 & $\begin{array}{l}\text { Medium to coarse quartzose } \\
\text { to quartzo-feldspatic sand }\end{array}$ & $\begin{array}{l}\text { Compacted fabric, } \\
\text { Q-overgrowth and clay } \\
\text { cemented framework }\end{array}$ & $\begin{array}{l}\text { Low porous, moderately low permeable, } \\
\text { poor-fair intergranular porosity, micro } \\
\text { to isolated dissolution meso pores }\end{array}$ \\
\hline \multirow{2}{*}{ Tight sand } & EF1 & 4 & $\begin{array}{l}\text { Medium to coarse sand } \\
\text { and some fine sand }\end{array}$ & $\begin{array}{l}\text { Compacted fabric, } \\
\text { Q-overgrowth and clay } \\
\text { cemented framework }\end{array}$ & $\begin{array}{l}\text { Moderately porous, low permeable, trace } \\
\text { intergranular porosity, poorly connected } \\
\text { micro to isolated meso pores }\end{array}$ \\
\hline & EF6 & 5 & $\begin{array}{l}\text { Medium to fine quartzose } \\
\text { and quartzo-feldspatic sand }\end{array}$ & $\begin{array}{l}\text { Compacted fabric, } \\
\text { Q-overgrowth and clay } \\
\text { cemented framework }\end{array}$ & $\begin{array}{l}\text { Low porous, moderately low permeable, } \\
\text { poorly connected micro pores }\end{array}$ \\
\hline \multirow{3}{*}{$\begin{array}{l}\text { Very tight to } \\
\text { tight sand }\end{array}$} & & 6 & $\begin{array}{l}\text { Medium to some and coarse } \\
\text { quartzose sand with some } \\
\text { shale partings }\end{array}$ & $\begin{array}{l}\text { Compacted fabric, } \\
\text { Q-overgrowth and clay } \\
\text { cemented framework }\end{array}$ & $\begin{array}{l}\text { Moderately porous, low permeable trace } \\
\text { intergranular porosity, poorly connected } \\
\text { micro to some isolated meso-pores }\end{array}$ \\
\hline & EF2 & 7 & $\begin{array}{l}\text { Fine to medium grained } \\
\text { mica rich sand }\end{array}$ & $\begin{array}{l}\text { Highly compacted fabric, } \\
\text { clay cemented framework }\end{array}$ & $\begin{array}{l}\text { Low to moderately porous, low permeable, } \\
\text { poorly connected pores }\end{array}$ \\
\hline & & 8 & $\begin{array}{l}\text { Medium to coarse } \\
\text { grained sand }\end{array}$ & $\begin{array}{l}\text { Compacted fabric, coarse } \\
\text { calcite cemented framework }\end{array}$ & $\begin{array}{l}\text { Low porous, low permeable, low } \\
\text { connected micro pores }\end{array}$ \\
\hline
\end{tabular}

- Local distribution of calcite cement within the reservoir has been recognized as pore occluding and also grain replacive, especially in coarse grained facies. Facies with significant calcite cement in their pore system, have very low porosity and permeability. These facies involve part of very tight to tight sandstones in the reservoir (RRT-8).

- Pore system includes isolated dissolution pores and also micro pores associated with authigenic clays. However their connection is through small remaining intergranular pores which especially are preserved in coarse grained sandstones.

- Study of reservoir rock types shows that all sandstone types are characterized by a compacted fabric and cemented framework, but medium to coarse/granular sandstones, mostly compatible with channel deposits, with medium to high porosity and moderately low permeability (RRT1 and RRT2) are the most promising intervals in the reservoir.

\section{Conclusions}

In this study, tight gas sandstones of the Whicher Range field were studied with respect to depositional, diagenetic and petrophysical characteristics. The study shows that tight sandstones have severely been affected by diagenetic events. Such events depend on primary depositional properties of reservoir sandstones, and have modified the pore system responsible for reservoir behavior in the field.

We recognized reservoir rock typing based on three depositional, diagenetic and petrophysical aspects of the reservoir sandstones, as a comprehensive and practical method to reveal internal reservoir heterogenity and to recognize main factors controlling pore system propeties. Consequently, eight reservoir rock types were recognized. All theses reservoir rock types are characterized by compacted fabric and cemented framework. But the pore system in each reservoir rock type, depends on depositional properties and distribution of diagenetic products, resulting in different properties, which differentiate it from other reservoir units. The results show that medium to coarse/granular sandstones, mostly related to channel deposits, with medium to high porosity and moderately low permeability are the most promising intervals from reservoir quality point of view. 


\section{Acknowledgements}

The authors extend their appreciation to the Whicher Range Energy for providing necessary data to perform this study and to permit us to publish this paper.

\section{References}

[1] Rezaee, R., Saeedi, A. and Clennell, B. (2012) Tight Gas Sands Permeability Estimation from Mercury Injection Capillary Pressure and Nuclear Magnetic Resonance Data. Journal of Petroleum Science and Engineering, 88-89, 92-99. http://dx.doi.org/10.1016/j.petrol.2011.12.014

[2] Stroker, T.M., Harris, N.B., Elliott, W.C. and Wampler, J.M. (2013) Diagenesis of a Tight Gas Sand Reservoir: Upper Cretaceous Mesaverde Group, Piceance Basin, Colorado. Marine and Petroleum Geology, 40, 48-68. http://dx.doi.org/10.1016/j.marpetgeo.2012.08.003

[3] Prodanovic, M., Bryant, S.L. and Davis, J.S. (2013) Numerical Simulation of Diagenetic Alteration and Its Effect on Residual Gas in Tight Gas Sandstones. Transport in Porous Media, 96, 39-62. http://dx.doi.org/10.1007/s11242-012-0072-3

[4] Bahrami, H., Rezaee, R. and Clennell, B. (2012) Water Blocking Damage in Hydraulically Fractured Tight Sand Gas Reservoirs: An Example from Perth Basin, Western Australia. Journal of Petroleum Science and Engineering, 88-89, 100-106. http://dx.doi.org/10.1016/j.petrol.2012.04.002

[5] Ziarani, A.S. and Aguilera, R. (2013) Pore-Throat Radius and Tortuosity Estimation from Formation Resistivity Data for Tight-Gas Sandstone Reservoirs. Journal of Applied Geophysics, 83, 65-73. http://dx.doi.org/10.1016/j.jappgeo.2012.05.008

[6] Zhang, L., Bai, G., Luo, X., Ma, X., Chen, M., Wu, M. and Yang, W. (2009) Diagenetic History of Tight Sandstones and Gas Entrapment in the Yulin Gas Field in the Central Area of the Ordos Basin, China. Marine and Petroleum Geology, 26, 974-989. http://dx.doi.org/10.1016/j.marpetgeo.2008.05.003

[7] Gan, Q., Xu, D., Tang, J. and Wang, Y. (2009) Seismic Resolution Enhancement for Tight-Sand Gas Reservoir Characterization. Journal of Geophysics and Engineering, 6, 21-28. http://dx.doi.org/10.1088/1742-2132/6/1/002

[8] Yao, J.L., Deng, X.Q., Zhao, Y.D., Han, T.Y., Chu, M.J. and Pang, J.L. (2013) Characteristics of Tight Oil in Triassic Yanchang Formation, Ordos Basin. Petroleum Exploration and Development, 40, 161-169. http://dx.doi.org/10.1016/S1876-3804(13)60019-1

[9] Zou, C., Zhu, R., Liu, K., Su, L., Bai, B., Zhang, X., Yuan, X. and Wang, J. (2012) Tight Gas Sandstone Reservoirs in China: Characteristics and Recognition Criteria. Journal of Petroleum Science and Engineering, 88-89, 82-91. http://dx.doi.org/10.1016/j.petrol.2012.02.001

[10] Yin, F., Liu, R.B. and Qin, H. (2013) About Origin of Tight Sandstone Gas: To Discuss with Academician Dai Jinxing. Petroleum Exploration and Development, 40, 134-138. http://dx.doi.org/10.1016/S1876-3804(13)60016-6

[11] Cadman, S.J., Pain, L. and Vuckovic, V. (1994) Perth Basin, W.A., Australian Petroleum Accumulations. Report No. 10, Bureau of Resource Sciences, Canberra.

[12] Mory, A.J., Haig, D.W., Mcloughlin, S. and Hocking, R.M. (2005) Geology of the Northern Perth Basin, Western Australia. A Field Guide. Western Australia Geological Survey, 71 p.

[13] Crostella, A. and Backhouse, J. (2000) Geology and Petroleum Exploration of the Central and Southern Perth Basin, Western Australia. Western Australia Geological Survey, Report 57, 85 p.

[14] Folk, R.L., Andrews, P.B. and Lewis, D.W. (1970) Detrital Sedimentary Rock Classification and Nomenclature for Use in New Zealand. New Zealand Journal of Geology and Geophysics, 13, 937-968. http://dx.doi.org/10.1080/00288306.1970.10418211

[15] Hall, P.B. and Kneale, R.L. (1992) Perth Basin Rejuvenated. Australian Petroleum Exploration Journal, 32, 33-43.

[16] Kadkhodaie-Ilkhchi, R., Rezaee, R., Moussavi-Harami, R. and Ali Kadkhodaie-Ilkhchi, A. (2013) Analysis of the Reservoir Electrofacies in the Framework of Hydraulic Flow Units in the Whicher Range Field, Perth Basin, Western Australia. Journal of Petroleum Science and Engineering, 111, 106-120. http://dx.doi.org/10.1016/j.petrol.2013.10.014

[17] Bear, J. (1972) Dynamics of Fluids in Porous Media. American Elsevier Publishing Company, New York, 764 p.

[18] Ebanks Jr., W.J. (1987) Flow Unit Concept-Integrated Approach to Reservoir Description for Engineering Projects. American Association of Petroleum Geologists Bulletin, 71, 551-552.

[19] Amaefule, J.O., Altunbay, M., Tiab, D., Kersey, D.G. and Keelan, D.K. (1993) Enhanced Reservoir Description: Using Core and Log Data to Identify Hydraulic (Flow) Units and Predict Permeability in Uncored Intervals/Wells. SPE Annual Technical Conference and Exhibition, 3-6 October 1993, Houston, 1-16.

[20] Amabeoku, M.O., Kersey, D.G., Bin Nasser, R.H., Al-Waheed, H.H. and Belowi, A.R. (2005) Incorporating Hydraulic 
Units Concepts in Saturation-Height Modeling in a Gas Field. SPE Asia Pacific Oil and Gas Conference and Exhibition, 5-7 April 2005, Jakarta, 17 p.

[21] Amabeoku, M.O., Kersey, D.G., Bin Nasser, R.H. and Belowi, A.R. (2006) Relative Permeability Coupled SaturationHeight Models Based on Hydraulic (Flow) Units in a Gas Field. SPE Reservoir Evaluation \& Engineering, 11, 10131028.

[22] Kadkhodaie-Ilkhchi, A. and Amini, A. (2009) A Fuzzy Logic Approach to Estimating Hydraulic Flow Units from Well Log Data: A Case Study from the Ahwaz Oilfield, South Iran. Journal of Petroleum Geolology, 32, 67-78. http://dx.doi.org/10.1111/j.1747-5457.2009.00435.x

[23] Svirsky, D., Ryazanov, A., Pankov, M., Corbett, P.W.M. and Posysoev, A. (2004) Hydraulic Flow Units Resolve Reservoir Description Challenges in a Siberian Oil Field. SPE Asia Pacific Conference on Integrated Modeling for Asset Management, Kuala Lumpur, 29-30 March 2004, 15 p. http://dx.doi.org/10.2118/87056-MS

[24] Serra, O. (1986) Fundamentals of Well Log Interpretation, the Interpretation of Logging Data. Vol. 2, Elsevier, Amsterdam, $684 \mathrm{p}$. 
Scientific Research Publishing (SCIRP) is one of the largest Open Access journal publishers. It is currently publishing more than 200 open access, online, peer-reviewed journals covering a wide range of academic disciplines. SCIRP serves the worldwide academic communities and contributes to the progress and application of science with its publication.

Other selected journals from SCIRP are listed as below. Submit your manuscript to us via either submit@scirp.org or Online Submission Portal.
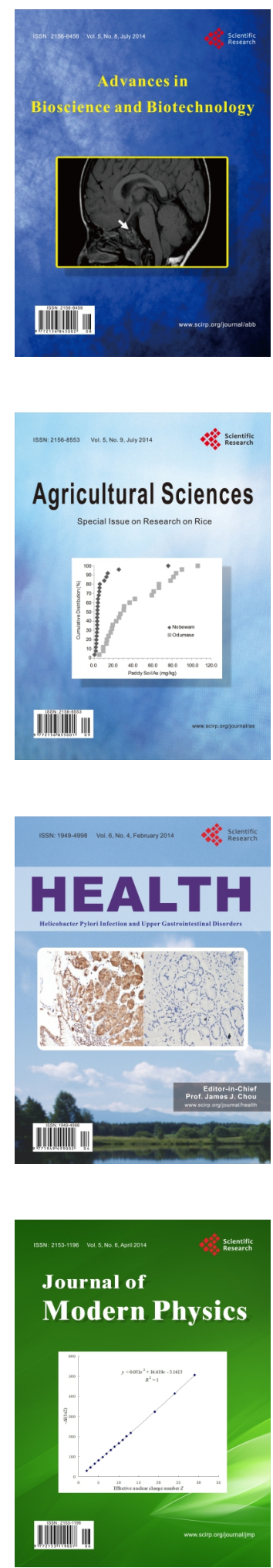
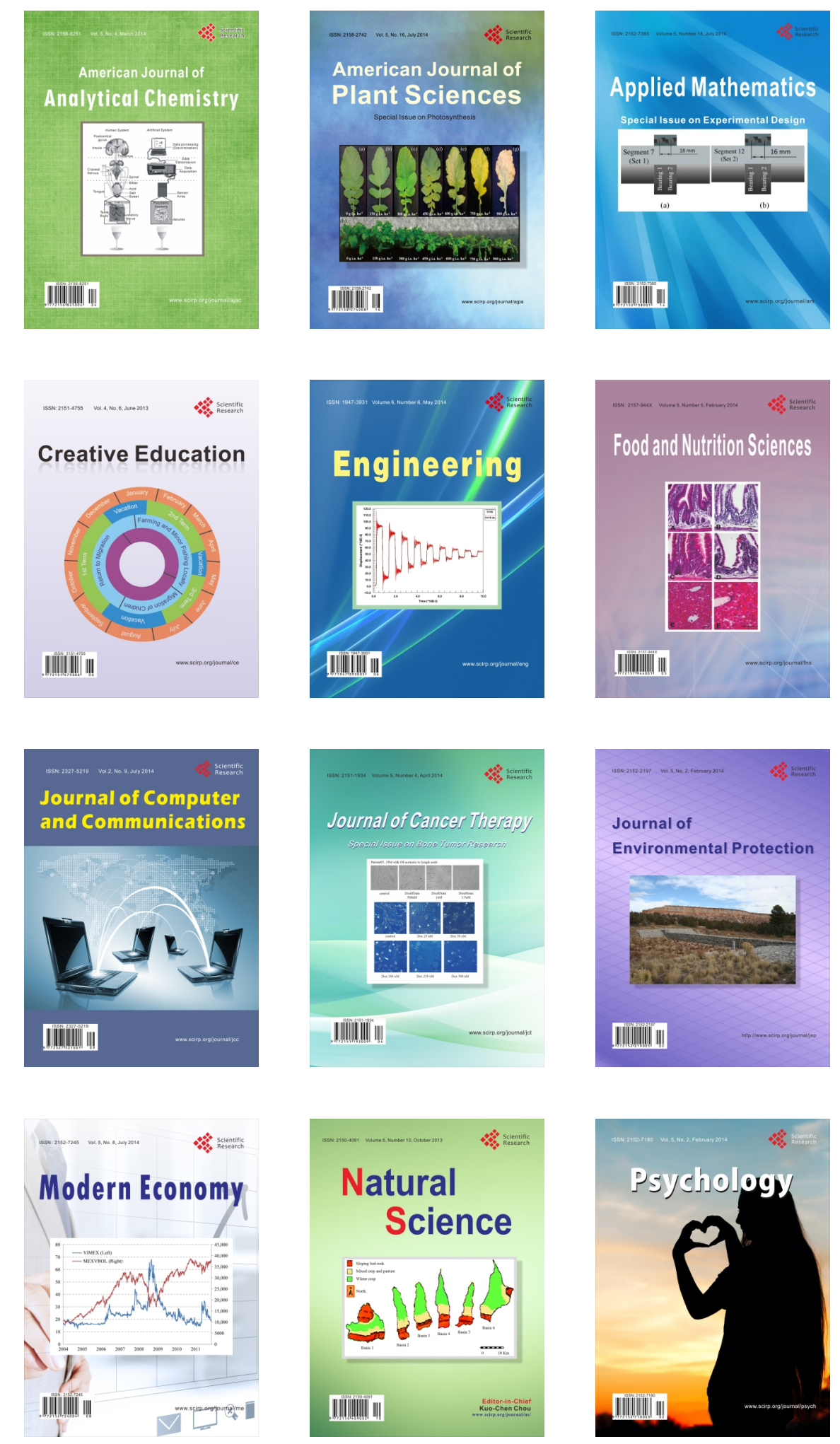